\title{
Intensive Archaeological Survey in Southeast Asia: Methodological and Metallurgical Insights from Khao Sai On, Central Thailand
}

\author{
(Q) (O) (O) \\ T. O. PRYCE, A. H. BEVAN, R. CiARla, F. RisPOli, C. CASTILlO, \\ B. HASSETT, AND J. L. MALAKIE
}

\section{INTRODUCTION}

INTENSIVE SURFACE SURVEYS ARE BY NOW A COMMON and well-established approach to understanding the archaeological landscapes of many parts of the world. However, they have hitherto remained relatively rare in Southeast Asian archaeology. In this paper we assess the potential contribution of such surveys in Southeast Asia, particularly with regard to archaeometallurgical landscapes. We also report the results of a short but intensive survey in the environs of Khao Sai On, in Changwat Lopburi, central Thailand (Fig. 1), that underlines some of the major strengths and weaknesses of this kind of approach in a Southeast Asian context. ${ }^{1}$

Located at the southern end of the Loei-Petchabun Volcanic Belt, the Lopburi area has long been known for its extensive evidence relating to early copper production (Natapintu 1988). During the last 30 years, Metal Age ${ }^{2}$ evidence for mining, smelting, and/or founding activity, often with associated settlement and funerary finds, have been reported at a range of different locations (Fig. 2). Of the metallurgical assemblages from these sites, however, only two (from the substantially larger sites of Non Pa Wai and Nil Kham Haeng, at c. 5 ha and 3+ ha respectively), have been subject to comprehensive technological analysis, first by Anna Bennett (1988, 1989), and more recently by the lead author with a reconstructed evolution of local metallurgical behaviors from competent copper-base founding c. 1300 B.C., to experimental smelting c. 500 B.C., to standardized and intensive production by c. 500 A.D. (Pryce 2009; Pryce et al. 2010). Non Pa Wai and Nil Kham Haeng also provided a substantial body of the evidence for Joyce White and Vincent Pigott's influential article (1996) on "community" contexts of copper production in pre-state Thailand. While our understanding of ancient metallurgy and associated ways of life in the Lopburi area is far

T. O. Pryce is affiliated with the Research Laboratory for Archaeology and the History of Art and St Hugh's College, University of Oxford, Oxford, United Kingdom. A. H. Bevan, C. Castillo, and B. Hassett are affiliated with UCL Institute of Archaeology, University College London, United Kingdom. R. Ciarla, and F. Rispoli are affiliated with Instituto Italiano per l'Africa e l'Oriente, Roma, Italia. J. L. Malakie is affiliated with the Department of Anthropology, University of Washington, Seattle, U.S.A. 


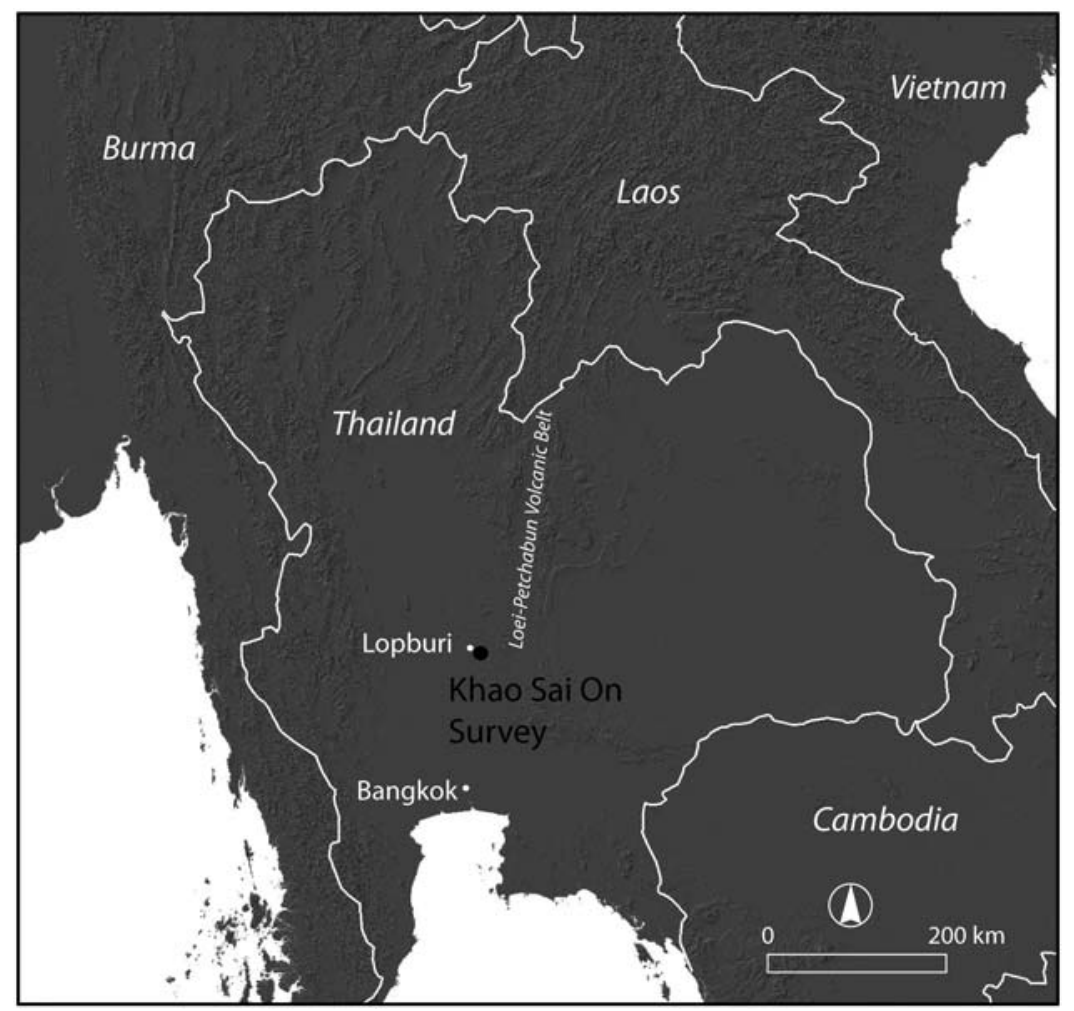

Fig. 1. Regional map indicating position of Khao Sai On survey area in relation to the Loei-Petchabun Volcanic Belt.

more detailed than anywhere else in Southeast Asia, the sample remains problematic, as it is both small and biased toward the largest sites.

Metal production and exchange was probably a substantial sector of the pre-modern Southeast Asian economy (see e.g., Bronson and Charoenwongsa 1994), and almost certainly a significant element of the human experience within the Lopburi area. We thus consider it a topic worthy of study in its own right. However, the comparative analysis of Eurasian metallurgical traditions has long constituted a valuable proxy for long-range cultural exchange, due to the dispersed resources and considerable skill required for successful metallurgy and the close and cooperative training environments needed for the high-fidelity transmission of these technologies (e.g., Chernykh 1992, 2008; Chernykh et al. 2000; Childe 1954; Chiou-Peng 1998; Grushin 2005; Linduff and Mei 2009; Mei 2000, 2004; Mei and Li 2003). Within the Southeast Asian arena there has been a recent spate of such modeling (Ciarla 2007b; Higham 1996; Higham et al. 2011; Pigott and Ciarla 2007; White and Hamilton 2009), all of them linking early regional metallurgy to the general Eurasian debate, albeit with contested chronologies, routings, and social interaction mechanisms. These hypotheses can be probed in terms of theoretical framework and methodology (Pryce 2009; Pryce et al. 2010), but their critical weaknesses are data density and quality, as they rely on evidence from metallurgical assemblages separated by hundreds if not 


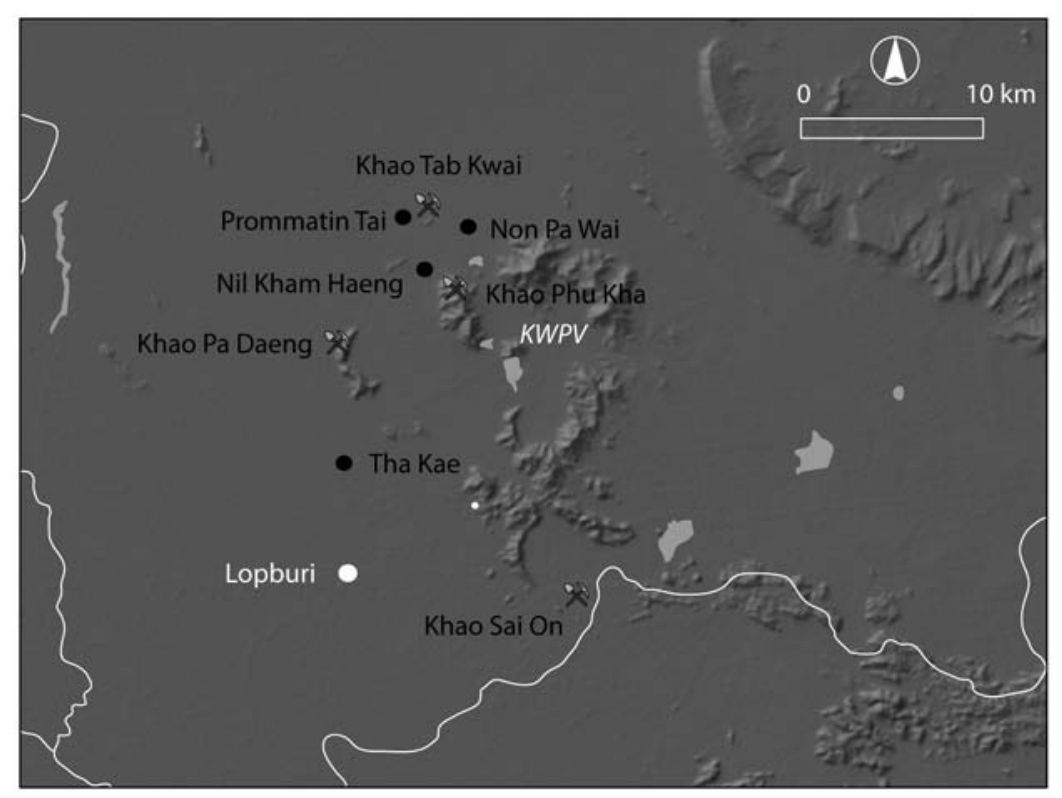

Fig. 2. Local map indicating position of Khao Sai On survey area in relation to the known mineralizations and metal production sites in and around the Khao Wong Prachan valley.

thousands of kilometers, which have for the most part not been studied in substantial detail. Therefore, our pilot landscape study was also indirectly motivated by the regional need to develop methodologies for the discovery of ancient metal production sites of all sizes, which would constitute the "stepping-stone" comparanda required to substantiate or reject the competing models for early Southeast Asian metallurgy. At local scales, a more holistic appreciation of site hierarchies in metal production landscapes will also serve to provide a clearer understanding of the social context of those industries.

Of course, the first problem is how to acquire a systematic sample of metal production sites within the Southeast Asian landscape. While remaining aware of the risks of assuming "optimal" economic behaviors ${ }^{3}$ and uniformitarian historical processes from the outset, it might nonetheless be useful to focus on those regions with metallogenic geology (e.g., Sitthithaworn 1990) and/or ethnographic accounts of primary metal production (e.g., Bronson and Charoenwongsa 1994). Even then, the enormous mineral wealth and cultural diversity of Southeast Asia still leaves vast territories to explore. To further reduce the task, satellite-based remote sensing approaches to identifying a signature for early smelting sites have been attempted, based on the chemical and textual characteristics of known Lopburi area production sites with a high proportion of slag in the ground (Pryce and Abrams 2010; see also Dentz 2008). Unfortunately, the limited size even of large locations (such as Non Pa Wai and Nil Kham Haeng), poor soil/slag discrimination, and the radiation shielding effects of vegetation dictate that this methodology requires substantial development, with vegetation signatures in slag-rich matrices being one avenue. In any event, remote sensing techniques can only ever offer "areas of interest" that will always require groundtruthing. This brings us to intensive and systematic survey methodologies. 
By "systematic" survey we refer to any landscape-scale, surface investigation of surface remains that has an explicit and consistent methodology, for which, most crucially, it is possible to indicate where surveyors have and have not walked. Such an approach allows researchers to identify any biases in survey coverage, to understand other limitations in the dataset, and even to conduct contiguous fieldwork. In contrast, an "extensive" or "reconnaissance" survey covers the landscape in a way that cannot be evaluated by peers; Onsuwan-Eyre (2006: chap. 6) provides a useful summary of Thai and foreign surveys of this nature. By "intensive" we mean that, in addition to being systematic, the survey covers the physical ground surface at a sufficient resolution to detect very small sites (in our case with surveyors spaced at $20 \mathrm{~m}$ intervals; see below). Our field walking methodology has much in common with those used regularly in Europe, the Mediterranean, and North and Central America, to name but the regions most densely explored in this manner (e.g., Balkansky et al. 2000; Berlin 1951; Cherry et al. 1991; Davis et al. 1997; Feinman and Nicholas 1996; Goggin 1943; Renfrew and Wagstaff 1982; Smith et al. 1994; Wilkinson 2000; Wright et al. 1990). The success of landscape archaeology projects in such varying but frequently difficult environments suggests that Southeast Asia's climate, terrain, and vegetation should not been seen as exceptional or intrinsic barriers to good results in this regard. Our efforts to provide a systematic central Thai survey dataset build upon the notable fieldwork of Karen Mudar (1992, 1995) and Chureekamol Onsuwan-Eyre (2003, 2006). However, while the latter two researchers' objectives were largely concerned with relationships between occupation and environment (agricultural potential), as well as site hierarchies, our survey was arguably less ambitious, seeking merely to emphasize the underappreciated value of recovering artifact distributions at the landscape scale in this region and to confirm intensive survey's capacity to detect very small scatters of metal production waste and associated ceramics. These scalar differences in research agendas are represented in our divergent terminologies, in which earlier central Thai projects have probably used "sites" to refer to entire settlements, whereas we aim to resolve (or at least indicate) potentially single household occupation, small activity areas and production loci. Also, while our survey had "archaeometallurgical" objectives, we recorded all surface archaeology as we are interested in all aspects of the social context of metal production. We wish to be clear that we do not advocate total coverage survey at the expense of excavation, upon whose chronologies we rely for the relative dating of survey assemblages, but rather suggest that survey and excavation are mutually compatible approaches that provide complementary datasets for a spatial and temporal understanding of a region's past.

Located about $20 \mathrm{~km}$ southeast of the main cluster of known metal production sites in and around the Khao Wong Prachan Valley (Fig. 2), Khao Sai On was an ideal location for a pilot study. Ongoing excavation by the Lopburi Regional Archaeology Project (LoRAP) had already identified two late Iron Age copper smelting locations at Khok Din and Noen Din in this area (c. 300 B.C. to c. 500/600 A.D. based on crossdating with very similar assemblages at Nil Kham Haeng) with associated late Iron Age and Dvaravati (c. 600 to 1000 A.D.) settlement and cemetery evidence, and an undated copper mine at Khao Sai On itself (Ciarla 2007a; 2008). In addition to a relatively well-understood ceramic sequence, the survey thus benefited from "control" sites that enabled us to broadly calibrate surface and subsurface archaeology. We were also able to test our methodology over varying ground cover as the local area con- 
tained a range of vegetation zones defined by land use. Agricultural land was primarily for cereal cultivation and at different stages of the agrarian cycle. Plots were plowed and ready for cropping, cropped (maize), or left fallow. Also present were patches of woodland and scrub (Acacia). Occasionally, palm oil and coconuts are planted as boundary dividers. Also notable was the boundary between the sedimentary floodplain and metamorphic limestone geological units running roughly north-south through the center of the study area.

To be more precise, we undertook this short survey with two main research objectives:

1. To field test a modified intensive survey methodology in a tropical Southeast Asian environment, with an interest in small-scale cultural remains of all periods, but a particular focus on metallurgical activity.

2. To understand the relation between primary metal extraction sites, smelting areas, and associated settlement landscapes at scales below those addressed by researchers up to present.

\section{METHODS}

\section{Surface Survey}

Intensive surveys typically cover the landscape in either a series of parallel walked lines or a formal grid, and quite often both in separate stages (e.g., Bevan et al. 2008). For this pilot project however, we were concerned to develop a scalable survey method that took the best from both of these strategies without leading to any time-consuming set-up procedures or any problems of comparison between differently implemented stages. We therefore broke the landscape up into three scales: notional $1 \times 1 \mathrm{~km}$ squares, within which the survey team walked $100 \times 100 \mathrm{~m}$ (ha-sized) squares, and within these, $10 \times 10 \mathrm{~m}$ squares that were the primary recording and collection units for finds (Fig. 3).

This allows surveyors to space themselves $10 \mathrm{~m}$ apart, walk down the center of a $10 \times 10$ grid square (thereby only observing a 2-3 m sample corridor in the square as in most line-walking survey methods), and record cultural material in $10 \mathrm{~m}$ intervals, creating a $10 \times 10 \mathrm{~m}$ grid, but without physically laying it out. A further advantage of this method is that a five-person team can choose to space themselves $20 \mathrm{~m}$ apart and walk only every other line of $10 \times 10 \mathrm{~m}$ squares. If greater resolution is required then the intervening squares can be surveyed afterward, but for our purposes in this pilot survey, we only walked every other set of $10 \times 10 \mathrm{~m}$ squares (Fig. 4). All artifacts were labeled with details of the three scales of collection unit and could thus be resolved to a $10 \times 10 \mathrm{~m}$ box. Each walker kept a record form for each $10 \times 10 \mathrm{~m}$ unit they covered, and the team leader duplicated much of this information and added further comments on vegetation, standing structures, etc., for the ha-sized unit. This level of recording also allows for systematic differences in walker recovery rates to be accounted for, as some people are better at spotting certain types of material than others (Banning 2002). Our paper-based recording system may be contrasted with mobile GIS approaches whose increased data entry speed may be offset by a risky reliance on electronic media in a tropical environment (as noted by Given and Hyla 2006), while wet paper can still be read. 


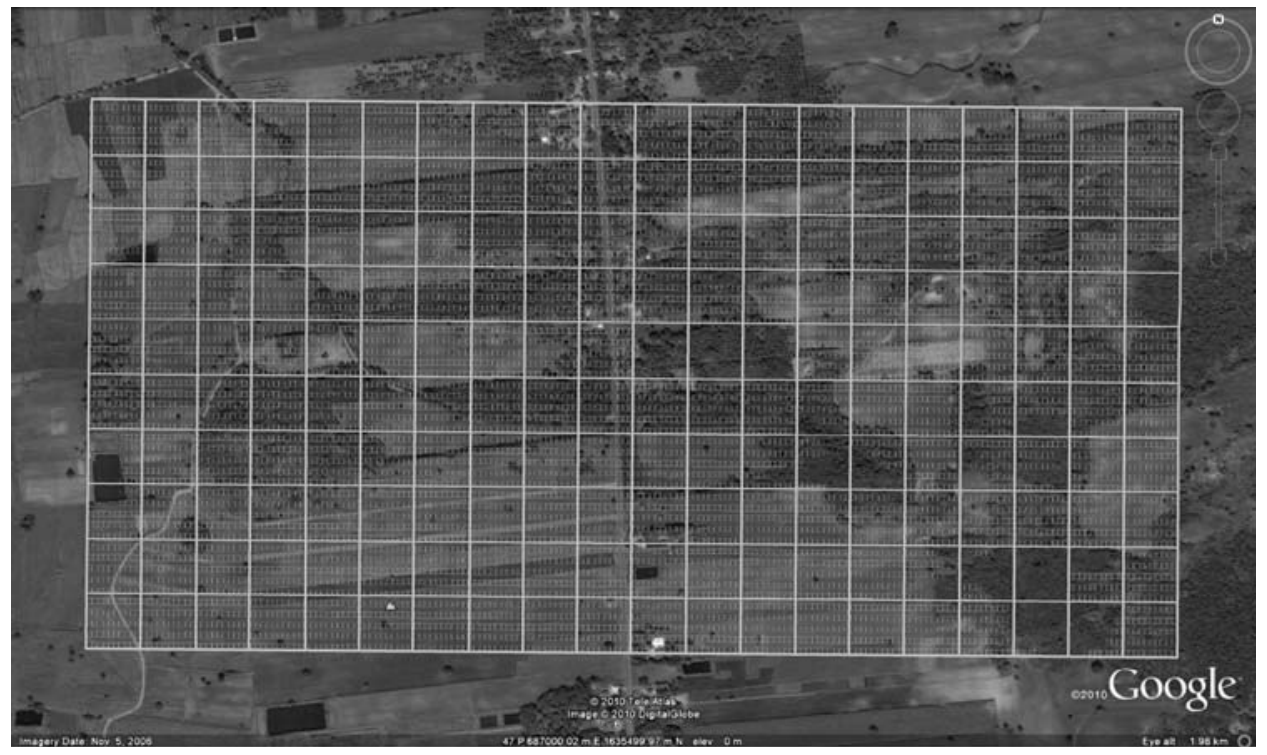

Fig. 3. The division of the Khao Sai On survey area into $1000 \mathrm{~m}, 100 \mathrm{~m}$, and $10 \mathrm{~m}$ units. The southwest corner of the illustrated survey grid is at $686000 \mathrm{E}, 1635000 \mathrm{~N}$ (UTM 47N, WGS84). Areas not surveyed by our team have been left unboxed. Underlying satellite imagery courtesy of Google Earth Mapping Services.

Prior to fieldwork, surveyors were familiarized with local artifact classes in the King Narai Palace National Museum in Lopburi, with particular emphasis paid to slag, minerals, and technical ceramics (e.g., Pryce and Natapintu 2009; Pryce et al. 2008). In higher artifact density environments (e.g., Bevan and Conolly 2009), it is typical to count all ceramics but to lift only diagnostics (e.g., bases, handles, rims, and decorated sherds) to reduce post-fieldwork processing, but in light of the fact that central Thai surface archaeology is comparatively poorly understood, we employed a complete collection policy for all ceramics and slag, as well as noting the distribution of crushed minerals.

The team leader's recording form also addressed land use and vegetation, along with an estimate of surface visibility - factors that obviously impact the ability of field walkers to identify areas of archaeological interest. This can operate both ways. A plowed field may offer very good surface visibility, but surface archaeology is more likely to be disturbed (Banning 2002). Conversely, a deep thicket of thorny Acacia (with formic friends) requires a degree of commitment to penetrate, but material culture distributions may be better preserved inside. Our capacity to navigate accurately was occasionally diminished by dense vegetation, but walker spacing and survey unit boundaries were closely monitored using recent satellite imagery and handheld Global Positioning System (GPS) units. Where the vegetation was completely impenetrable, the tracts, or individual walker paths, were marked as unsurveyed (Fig. 3). With this methodology, we can state with reasonable confidence the location of material culture distributions in the $2 \mathrm{~km}^{2}$ assessed, and for those areas where we were less certain or unable to look, we can identify the factors responsible (typically vegetation) and account for them in our interpretations. 

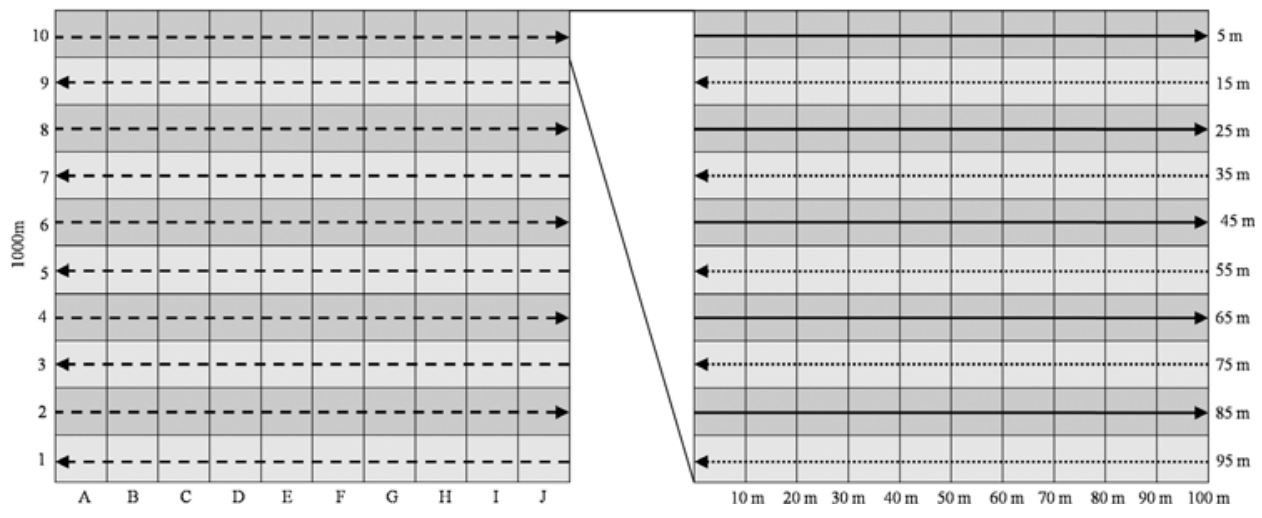

Fig. 4. Schematic indicating the walking pattern of a $1 \mathrm{~km}^{2}$ grid square (left), and the spacing a direction of walkers within a 1 ha tract (right).

\section{Digital Infrastructure}

This project, in common with many other intensive surveys around the world, used Geographic Information Systems to manage its spatial datasets and to design the initial survey coverage (e.g., Bevan and Conolly 2004; Conolly and Lake 2006). We were, however, interested in seeing how far we could limit the up-front costs of survey design and in-the-field navigation by using a combination of freely available highresolution satellite imagery (specifically, the pan-sharpened Quickbird coverages made available by Digital Globe through Google Earth for many areas of the world) and relatively cheap handheld GPS units. We made use of a semi-automated GIS method to create, georeference (to UTM 47N WGS84), and assign unique identifiers to our $10 \times 10 \mathrm{~m}$ polygonal grid. All finds were then assigned a random $\mathrm{x}$, y location within the notional grid square whence they came, allowing us to point-plot finds without the awkward one-to-many joins and graduated symbologies that are otherwise a typical method for display survey finds within survey units (e.g. Gallant 1986). The findspots for individual potsherds that we depict in this paper's figures and that accompany our digital data should thus have a $\pm 10 \mathrm{~m}$ relative error within the survey area, on top of the absolute error from our use of handheld GPS (typically $\pm 4 \mathrm{~m})$.

\section{Artifact Study}

Survey pottery is commonly abraded due to long-term exposure to the elements, with a subsequent reduction in morphological and/or decorative detail. Nevertheless, familiarity with fabrics excavated and radiometrically dated in the locality (e.g., Ciarla 1992, 2007a, 2008; Rispoli 1990, 1992, 1997, 2007; Rispoli et al. 2009) can render even highly fragmentary ceramics to some degree chronologically diagnostic. The pottery finds from this survey have been permanently collected and stored in the King Narai Palace Museum, rather than studied in the field, in order to allow opportunities for future reassessment. They were each macroscopically examined and given provisional dates, shape attributions, size measurements, and general descriptions. Collected slag was assessed by the lead author based on experience with metallurgical 
materials in the Lopburi area (e.g., Pryce 2009; Pryce et al. 2010). This was predominantly a screening to ensure that "slag" was indeed slag. Non-excavated slag is unsuitable for technological study due to uncertainties over its representativeness and often heavy post-depositional alteration (e.g., Humphris et al. 2009). Nor can slag be directly dated by its morphological characteristics, ${ }^{4}$ and thus periodization relies on other associated artifacts. Nevertheless, bearing in mind possible taphonomic displacements, a concentration of slag, minerals, and/or technical ceramics in the survey area was considered to represent a metal production locus.

\section{RESULTS}

\section{Pottery}

In total, 1447 potsherds were collected from the study area, but of these, only some 25 percent were sufficiently diagnostic to allow periodization. The datable material indicates some 2300 years of activity in and around Khao Sai On. A few potsherds were associated with the very recent material from the village of Ban Nikhom Sam and are not discussed further. A further 86 sherds, dominated by red wares but also including corded red wares, molded red wares, slipped red wares, basket-impressed wares, and buff wares were bracketed within the Mid/Late Iron Age of the Lopburi area chronological sequence, 300 B.C.-A.D. 500/600 (Rispoli et al. 2009). With 266 fineware, coarseware, and basket-impressed coarseware sherds, by far the largest body of identified ceramics belonged to the period broadly known as Dvaravati, c. 6001000 A.D. Four glazed stoneware potsherds were identified as Late Historic, corresponding to the thirteenth and fourteenth centuries A.D. Two potsherds were identified as Sawankhalok celadon and one as a Sukhothai stoneware, all dated to the Sukhothai Kingdom period (mid-thirteenth to early fifteenth century A.D.) (Wyatt 2003). One sixteenth-century A.D. Chinese celadon was identified. Five stamped potsherds were dated to the late Ayutthaya Kingdom period (sixteenth to eighteenth century A.D.) (Wyatt 2003). Due to either their small size or heavy abrasion it was not possible to date the remaining 1075 potsherds, but they can certainly be considered pre-modern. No ceramics of the Lopburi period (c. tenth to thirteenth century A.D.) were detected, and no material before c. 300 B.C.

\section{Metallurgical Materials}

Overall, 27 fragments of slag, 5 possible furnace fragments, and 2 possible crucible fragments were collected during the survey, though much more was visible on the surface between walked survey lines. Of the collected slag, 7 pieces had visible copper staining, but there is no reason to doubt that the others were not also related to copper production. All of the slag was of a reasonable homogeneity, neither glassy nor visibly partially reacted. Macroscopically, the Khao Sai On survey slag would seem more consistent with copper production at Nil Kham Haeng (c. 300 B.C. to 500 A.D.) than at Non Pa Wai (c. 500 to 300 B.c.), both sites c. 20 km northwest (Pryce 2009; Pryce et al. 2010), but further analytical work on excavated samples would be necessary to confirm this impression. The possible furnace fragments were identified by their coarse red fabric, as seen in near complete examples at Nil Kham Haeng (Pigott et al. 
1997) and Khok Din (Ciarla 2007a). It should be noted that based on technological analysis and experimental testing of Nil Kham Haeng furnace fragments, they are no longer thought to relate to copper smelting, but could represent associated foundry activities (Pryce 2009; Pryce et al. 2010). Two possible crucible fragments, recovered from the same $10 \times 10 \mathrm{~m}$ survey unit, were identified as such by their vitrified, bloated, and partially slagged fabric, but it is not certain whether they relate to copper smelting and/or founding.

\section{Locations of Denser Activity}

Due to the strong potential for surface archaeology to be displaced over time (e.g., plowing, gravity, and water), archaeologists are reluctant to label an artifact cluster a "site" until its subsurface continuity and character has been tested by excavation (e.g., Banning 2002; Sullivan et al. 2007), and the term may have varying theoretical utility in different cultural contexts (e.g., Bevan and Conolly 2004:128-132; Dunnell and Dancey 1983). For simplicity here, we simply make reference to interesting material concentrations at different numbered locations and speculate further on their nature where possible. The distribution of all ceramic and slag finds across the study area can be seen in Figures 5 and 6, alongside locations datable to particular periods of interest. Overall, the survey data indicate the presence of tens of previously unreported locations of denser activity in the study area, and many of these appear to have been small settlements.

The distribution of slag and technical ceramics, plus recorded but uncollected crushed mineral, would indicate seven new copper production loci (Fig. 5) in addition to the known sites. ${ }^{5}$ Of these, Locations 2 and 7-10 (including Khok Din) in the western part of the study area are arguably associated with the copper mines at Khao Sai On (Location 1), but Locations 3-6 identified in the southeast quadrant may relate to a possible mineralization at an inselberg c. $500 \mathrm{~m}$ to the south, outside the survey area.

Although excavation would be necessary to determine the true extent of the new production areas, the survey data suggest that they were extremely small, of a different order of magnitude than the 3-5 ha sites of Non Pa Wai and Nil Kham Haeng in the nearby Khao Wong Prachan Valley (Pigott et al. 1997). Based upon associated pottery, the majority of the new metallurgical locations should be dated to approximately 300 B.C. to A.D. 500/600, which is entirely consistent with the excavated sites of Khok Din and Noen Din (Ciarla 2007a; 2008). The latter site does have Dvaravati (c. 600 to 1000 A.D.) material but not in metal production contexts. While many of the Iron Age metallurgical loci likewise have a distribution of Dvaravati potsherds, Location 10 is unique in having produced slag exclusively in association with Dvaravati ceramics, suggesting the production is likely to be dated to this period.

\section{DISCUSSION}

People currently living and working in a locality indisputably know their land better than an outsider visiting for a matter of days, weeks, or months, and thus local knowledge is certainly a valuable asset to archaeologists seeking to identify sites. Nevertheless, for the most part, local people are not archaeologists and may be unable 


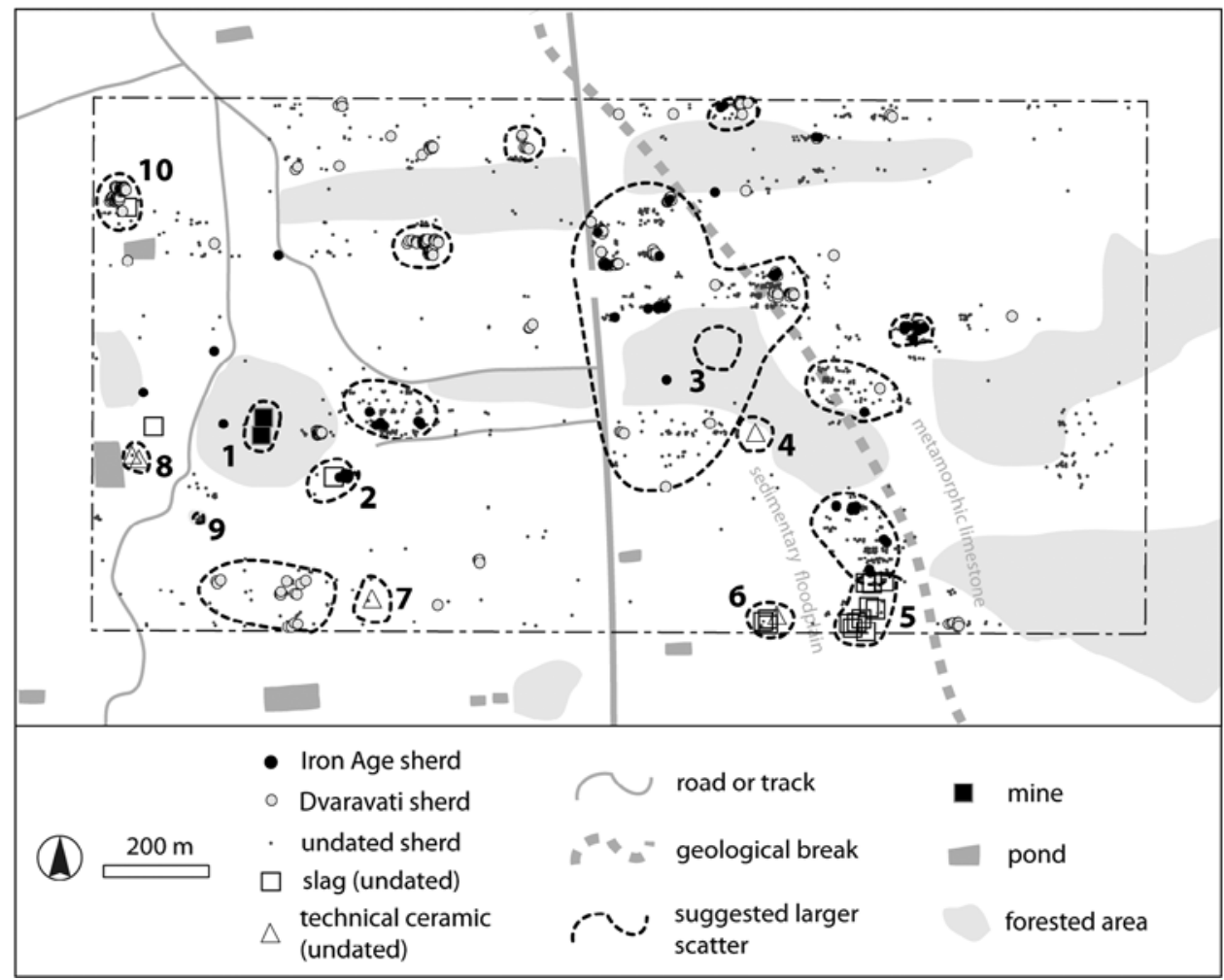

Fig. 5. Distribution of Iron Age and Dvaravati locations marked by datable potsherds in the Khao Sai On survey area, in addition to undated potsherds and metallurgical locations marked by finds of slag and/or technical ceramic.

to recognize certain features and/or materials, and thus an undue reliance on their testimony may lead to landscape evidence being overlooked. To complicate matters, local people may perceive economic or social reasons (usually property development and religious considerations, respectively) for inaccurately reporting or omitting to divulge known sites. We do not believe this to have been an issue in Ban Nikhom Sam, but despite their welcoming attitude toward us, local inhabitants suggested that there was no archaeology beyond the known loci at Khok Din and Noen Din. We believe that we have demonstrated this not to be case and argue that while terrain, climate, and vegetation vary widely at multiple geographical scales, with geomorphological foresight and perseverance, near complete coverage at a systematic survey intensity can often be achieved by motivated surveyors. Despite the value of satellite prospection (e.g., multispectral characterization) or of perusing archival collections (e.g., those kept in local monasteries), there is simply no replacement for systematic, on-the-ground coverage of archaeological landscapes by experienced observers (Fish and Kowalewski 1990).

A $2 \mathrm{~km}^{2}$ pilot survey can certainly be expanded on, but was able to document c. 2300 years of human activity at a vastly more numerous range of locations in the landscape than that known before. The most directly comparable Thai surveys (Mudar 


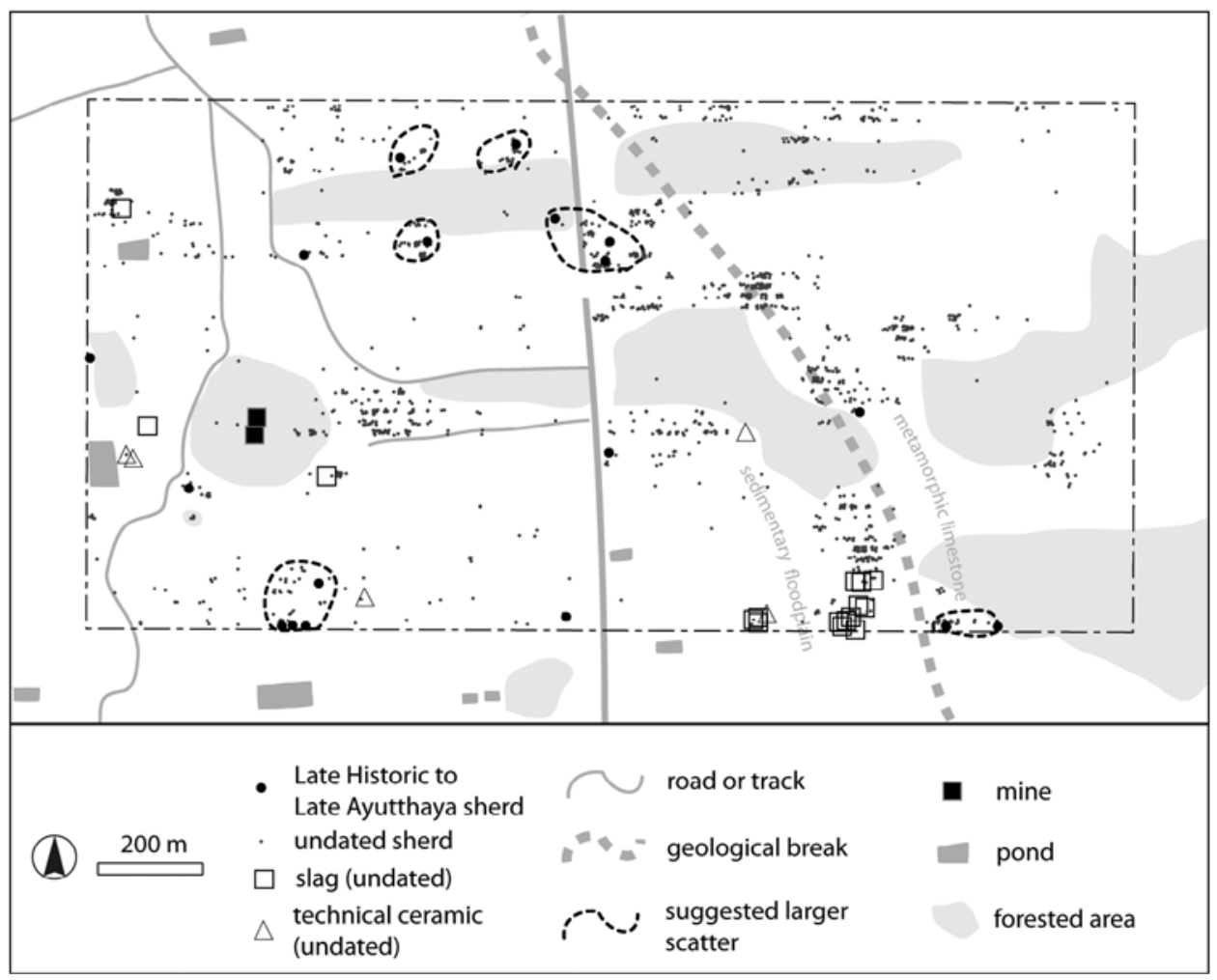

Fig. 6. Distribution of Late Historic to Late Ayutthaya locations marked by datable potsherds in the Khao Sai On survey area, in addition to undated potsherds and metallurgical locations marked by finds of slag and/or technical ceramic.

1995; Onsuwan-Eyre 2003) each covered c. $60 \mathrm{~km}^{2}$ but did not provide a seamless mapping of surface material; recording and collecting was only initiated once a distribution had been designated as a site. In the admittedly fairly amenable walking conditions in much of central Thailand, a 5-person team can cover about 20 ha per day at $10 \mathrm{~m}$ resolution or 40 ha at $20 \mathrm{~m}$ resolution. The deployment of 3 or 4 teams for several weeks thus means coverage in the order of 60 ha is entirely reasonable for a fieldwork season. Moreover, unbroken coverage of the landscape in contiguous blocks (rather than lots of small patches) is important for understanding the relationship between individual scatter locations. We would argue strongly that unbroken and intensive survey coverage at some meaningful resolution in Southeast Asia is often feasible (excluding some very mountainous and/or jungle environments) and with geomorphological forethought (see, e.g., Ciarla and Natapintu 1992) can provide an unprecedented understanding of diachronic landscape usage.

Turning to metallurgical activity in the region, three elements of the survey data are worth noting: (1) the comparatively high density of production areas; (2) the tentative identification of Dvaravati copper production; and (3) variation in size of production locations. In Figure 2 we plotted the location of 8 known mining/smelting/ founding sites in a c. $2400 \mathrm{~km}^{2}$ area around Lopburi. In contrast, our survey data 
indicate the presence of up to 10 production areas ( 7 new, 3 already known) in just $2 \mathrm{~km}^{2}$. Obviously part of this discrepancy in density reflects much higher occurrences of metal production areas in the metallogenic uplands, but it does also suggest that, as previously suspected (e.g. Pigott et al. 1997), there are many metallurgical sites, of a variety of shapes and sizes, that remain to be recorded in the area. Given that excavating numerous Lopburi area metal production sites would be prohibitively expensive and suffer from rapidly diminishing returns, what can intensive survey offer? Well, expanding our survey coverage substantially ${ }^{6}$ to cover both lowland and upland zones would enable us to provide a probabilistic estimate of the total number of production and settlement loci in the area. In addition to tracking changing land-use patterns over time, the periodicity of these sites can permit long-term population estimates, as their size hierarchy and patterning potentially offer hints at previous configurations of social complexity and the social context of metal production across the Loei-Petchabun Volcanic Belt, a probable prehistoric production zone fulfilling demand from the Khorat Plateau (White and Pigott 1996).

The possible identification of a Dvaravati copper production location (10) is also significant as it would constitute the first evidence for post-500/600 A.D. copper production in the Lopburi region, and only the second in Thailand (for the other, Phu Lon, see Pigott and Weisgerber 1998). The apparent diminution of Thai copper supply in the Early Historic period prompts one to question if this reflects a reduction in regional demand, or if the market was being suppressed by copper/bronze production elsewhere, possibly China (as remarked upon by Bronson 1992). In any event, a long-term academic concentration on prehistoric metallurgy could do with being re-balanced to give greater attention to historic period production and consumption, with intensive survey providing a cost-effective and comparatively rapid means of achieving this.

Finally, and as mentioned earlier, scalar and spatial relationships between contemporary settlement and metal production sites offer clues as to the social context of production. Joyce White and Vincent Pigott (1996), for example, argue that economic specialization need not automatically correlate with political centralization, and in particular they cite the Khao Wong Prachan Valley as evidence of intensive copper production in a social context with no clear evidence of control over that production either by local hierarchies or from further afield. Khao Wong Prachan Valley copper production very much appears to have been a community activity, although technological analysis does suggest that the industry's labor costs did rise significantly over the period 300 B.C. to A.D. 500 (Pryce 2009; Pryce et al. 2010).

What the excavation and survey around Khao Sai On bring to this discussion is an increasing sense of the dispersion of copper production across the landscape in units of widely varying size. Indeed, some of the production areas we identified seem too small to represent features of large-scale, community-organized industry and could conceivably be the result of copper mining, smelting, and founding activities being pursued by individual households. If correct, these data would strongly support White and Pigott's (1996) thesis for regional specialization unrestricted by elites. However, recent shifts in the central Thai chronology (Rispoli et al. 2009) mean that the attested intensification of copper production could now be seen as contemporary with increasing sociopolitical complexity and even early state formation in Iron Age mainland Southeast Asia (Higham and Higham 2009; Pryce 2009; Pryce et al. 2010), so while Lopburi-area copper production may well not have been part of a centralized 
economy, it does seem to have been closely correlated to regional demands for metal for social display. In any case, what we hope this discussion of intensive survey methods and results indicates is that there is much to be gained from more fully integrating systematic landscape survey into wider Southeast Asian research agendas.

\section{ACKNOWLEDGMENTS}

We are indebted to Khun Pakpadee Yokonkdee, LoRAP co-director and director of the Lopburi Office of the Thai Fine Arts Department; Khun Manita Keunkun, director of the King Narai Palace National Museum in Lopburi, as well as her staff; and also Khun Pira Venunan for a range of help and advice. Elizabeth Malakie kindly took part in field walking despite otherwise being on holiday. In Bangkok, our work was facilitated by the Central Office of the Thai Fine Arts Department and the Thai National Research Council. We are also grateful for the warm welcome extended to us by the headman and other villagers of Ban Nikhom Sam. The article was written while Pryce was a Leverhulme Trust Early Career Fellow at the Research Laboratory for Archaeology and the History of Art at the University of Oxford, and a Junior Research Fellow at St Hugh's College, Oxford; their combined support is gratefully acknowledged.

\section{ENDNOTES}

1. This survey was carried out in March 2009 under the auspices of the Lopburi Regional Archaeology Project (LoRAP; see, e.g., Ciarla 2005, 2007a, 2008). Our digital datasets are available from the first author on request.

2. The start of the Thai Metal Age is disputed, with the chronological extremes occupied by Joyce C. White and Elizabeth Hamilton (2009) who favor c. 2000 B.c. and Charles Higham et al. (2011) who have advocated c. 1000 B.C.

3. Mining activities by definition occur in metal-rich areas, but smelting may take place near fuel or clay sources, or somewhere more "illogical."

4. Though ${ }^{14} \mathrm{C}$ of charcoal inclusions is certainly possible.

5. It is notable that although a sizeable amount of crushed mineral was recorded at the known site of Khok Din (Ciarla 2007a) field walkers collected few potsherds and no slag as the slag scatter was spatially very concentrated and its core lay wholly within the $20 \mathrm{~m}$ gap between two walkers (Fig. 4). While this may appear to be a problematic omission, we stress that our intensive survey methodology was designed to be a systematic sampling of the landscape and cannot detect every last surface scatter.

6. There are numerous military bases in the vicinity, making full coverage unlikely.

\section{REFERENCES CITED}

Balkansky, A. K., S. A. Kowalewski,, V. Pérez Rodríguez, T. J. Pluckhahn, C. A. Smith, L. R. Stiver, D. Beliaev, J. F. Chamblee, V. Y. Heredia Espinoza, and R. Santos Pérez

2000 Archaeological Survey in the Mixteca Alta of Oaxaca, Mexico. Journal of Field Archaeology $27: 365-389$

BANNING, E. B.

2002 Archaeological Survey. New York: Kluwer Academic/Plenum Publishers.

Bennett, A.

1988 Copper Metallurgy in Central Thailand. Unpublished doctoral thesis, Institute of Archaeology, University College London, U.K.

1989 The contribution of metallurgical studies to South-East Asian archaeology. World Archaeology $20: 329-351$.

BerLin, $\mathrm{H}$.

1951 A survey of the Sola Region in Oaxaca, Mexico. Ethnos 16:1-17.

Bevan, A., And J. Conolly

2004 GIS, archaeological survey, and landscape archaeology on the Island of Kythera, Greece. Journal of Field Archaeology 29:123-138. 
2009 Modelling spatial heterogeneity and nonstationarity in artifact-rich landscapes. Journal of Archaeological Science 36: 956-964.

Bevan, A. J. Conolly, and A. Tsaravopoulos

2008 The fragile communities of Antikythera. Archaeology International 10:32-36.

BRONSON, B.

1992 Patterns in the early Southeast Asian metals trade, in Metallurgy, Trade and Urbanism in Early Thailand and Southeast Asia: 63-114, ed. I. Glover, P. Suchitta, and J. Villiers. Bangkok: White Lotus.

Bronson, B., And P. Charoenwongsa

1994 Eyewitness accounts of early mining and smelting in Southeast Asia. SPAFA Journal 4:4-17.

Chernykh, E. N.

1992 Ancient Metallurgy in the USSR: The Early Metal Age. Cambridge: Cambridge University Press.

2008 Formation of the Eurasian "Steppe Belt" of stockbreeding cultures: Viewed through the prism of archaeometallurgy and radiocarbon dating. Archaeology, Ethnology and Anthropology of Eurasia $35: 36-53$.

Chernykh, E. N., L. I. Avilova, and L. B. Orlovskaja

2000 Metallurgical Provinces and Radiocarbon Chronology. Moscow: Rossijskaja Akademija Nauk, Institut Arkheologii.

Cherry, J. F., J. L. Davis, and E. Mantzourani

1991 Landscape Archaeology as Long-Term History: Northern Keos in the Cycladic Islands from Earliest Settlement to Modern Times. Los Angeles: Monumenta Archaeologica.

Childe, V. G.

1954 The Socketed Celt in Upper Eurasia. Annual Report of the Institute of Archaeology of the University of London 10:11-25.

Chiou-Peng, T.

1998 Western Yunnan and Its Steppe Affinities, in The Bronze Age and Early Iron Age Peoples of Eastern Central Asia: 280-304, ed. V. H. Mair. Washington, DC: Institute for the Study of Man.

Ciarla, R.

1992 The Thai-Italian Lopburi Archaeological Project (LoRAP): Preliminary Results, in Southeast Asian Archaeology 1990:111-128, ed. I. C. Glover. Hull University, Centre for South-East Asian Studies.

2005 The Thai-Italian "Lopburi Regional Archaeological Project": As survey of fifteen years of activities, in La cultura Thailandese e le relazion: Italo-Thai, ed. I. Piovano. Torino: CESMEO.

$2007 a$ A preliminary report on Lo.R.A.P. archaeological excavations at prehistoric Khao Sai on, Lopburi Province, Central Thailand. East and West 57:395-401.

$2007 b$ Rethinking Yuanlongpo: The case for technological links between the Lingnan (PRC) and Central Thailand in the Bronze Age. East and West 57:305-328.

2008 The Thai-Italian "Lopburi Regional Archaeological Project" (LoRAP). Excavation at Khao Sai on-Noen Din 2008. Preliminary report. East and West 58:313-336.

Ciarla, R., and S. Natapintu

1992 Towards a definition of site formation processes in monsoonal environments: Preliminary observations (in Italian), in Proceedings of the International Seminar "Formation Processes and Excavation Methods in Archaeology: Perspectives," July 15-21:173-198, ed. G. Leonardi. University of Padua.

Conolly, J., And M. Lake

2006 Geographical Information Systems in Archaeology. Cambridge: Cambridge University Press.

Davis, J. L., S. E. Alcock, J. Bennet, Y. Lolos, and C. Shelmerdine

1997 The Pylos Regional Archaeological Project, part I: Overview and the archaeological survey. Hesperia 66:391-494.

Dentz, F.

2008 On the Use of Spaceborne Remote Sensing for Archaeology: A Case Study on Early Iron Reduction Sites at the Jordan Valley. Unpublished M.Sc. Geomatics diss. Department of Earth Observation and Space Systems, Delft University of Technology, The Netherlands.

Dunnell, R.C., AND W. S. DANCEY

1983 The siteless survey: A regional scale data collection strategy. Advances in Archaeological Method and Theory $6: 267-287$. 
Feinman, G. M., AND L. M. Nicholas

1996 Defining the eastern limits of the Monte Albán state: Systematic settlement pattern survey in the Guirún Area, Oaxaca, Mexico. Mexicon 18:91-97.

Fish, S. K., AND S. A. Kowalewski, eds.

1990 The Archaeology of Regions: A Case for Full-Coverage Survey. Washington, DC: Smithsonian Institution.

Gallant, T. W.

1986 "Background noise" and site definition: A contribution to survey methodology. Journal of Field Archaeology 13: 403-418.

Given, O., AND S. Hyla

2006 Forging partnerships in Laos: Archaeological survey using mobile GIS. Expedition 48:3839.

Goggin, J.

1943 An archaeological survey of Río Tepalcatepec Basin, Michoacán, Mexico. American Antiquity $9: 44-58$.

Grushin, S. P.

2005 Origins of various design elements in Seima-Turbino bronze artifacts. Archaeology, Ethnology and Anthropology of Eurasia 2:61-67.

Higham, C. F. W.

1996 The Bronze Age of Southeast Asia. Cambridge: Cambridge University Press.

Higham, C. F. W. and T. Higham

2009 A new chronological framework for prehistoric Southeast Asia, based on a Bayesian model from Ban Non Wat. Antiquity 82:1-20.

Higham, C., T. Higham, R. Ciarla, K. Douka, A. Kijngam, and F. Rispoli

2011 The Origins of the Bronze Age of Southeast Asia. Journal of World Prehistory 24:227-274.

Humphris, J., M. M. Torres, T. Rehren, And A. Reid

2009 Variability in single smelting episodes - a pilot study using iron slag from Uganda. Journal of Archaeological Science 36:359-369.

Linduff, K. M., AND J. Mei

2009 Metallurgy in ancient eastern Asia: Retrospect and prospects. Journal of World Prehistory $22: 265-281$.

MEI, J.

2000 Copper and Bronze Metallurgy in Late Prehistoric Xinjiang. Oxford: Archaeopress.

2004 Early copper-based metallurgy in China: Old question, new perspective. Bulletin of Archaeology, University of Kanazawa 27:109-118.

MeI, J., AND Y. LI

2003 Early copper technology in Xinjiang, China: The evidence so far, in Mining and Metal Production through the Ages: 111-121, ed. P. T. Craddock and J. R. S. Lang. London: The British Museum Press.

MudAR, K.

1992 Prehistoric and Early Historic Settlements on the Central Plain: Analysis of an Archaeological Survey in Lopburi Province, Thailand. Unpublished Ph.D. diss. University of Michigan, Ann Arbor.

1995 Evidence for prehistoric dryland farming in mainland Southeast Asia: Results of regional survey in Lopburi Province, Thailand. Asian Perspectives 34 : 157-194.

Natapintu, S.

1988 Current research on ancient copper-base metallurgy in Thailand, in Prehistoric Studies: The Stone and Metal Ages in Thailand: 107-124, ed. P. Charoenwongsa, P. Bronson, and B. Bronson. Bangkok: The Thai Antiquity Working Group.

Onsuman-Eyre, C.

2003 Metal Age complexity in Thailand: Socio-political development and landscape use in the Upper Chao Phraya Basin. Bulletin of the Indo-Pacific Prehistory Association 23:7-13.

2006 Prehistoric and Proto-Historic Communities in the Eastern Upper Chao Phraya RiverValley. Ph.D. diss. University of Pennsylvania, Philadelphia. 
Pigott, V. C., and R. Ciarla

2007 On the origins of metallurgy in prehistoric Southeast Asia: The view from Thailand, in Metals and Mines: Studies in Archaeometallurgy: 76-88, ed. S. L. Niece, D. Hook, and P. Craddock. London: Archetype Publications Ltd.

Pigott, V. C., K. Mudar, A. Agelarakis, L. Kealhofer, S. A. Weber, and J. C. Voelker

2006 A program of analysis of organic remains from Prehistoric copper-producing settlements in the Khao Wong Prachan Valley, Central Thailand: A progress report, in Uncovering Southeast Asia's Past. Selected Papers from the 10th International Conference of the European Association of Southeast Asian Archaeologists: 154-167, ed. E. A. Bacus, I. C. Glover, and V. C. Pigott. Singapore: National University of Singapore.

Pigott, V. C., AND G. Weisgerber

1998 Mining archaeology in geological context. The Prehistoric copper mining complex at Phu Lon, Nong Khai Province, Northeast Thailand, in Metallurgica Antiqua: In Honour of Hans-Gert Bachmann and Robert Maddin: 136-161, ed. J. D. Muhly. Bochum: Deutsches BergbauMuseum Bochum.

Pigott, V. C., A. Weiss, and S. Natapintu

1997 Archaeology of copper production: Excavations in the Khao Wong Prachan Valley, Central Thailand, in South-East Asian Archaeology 1992. Proceedings of the Fourth International Conference of the European Association of South-East Asian Archaeologists. Rome, 28th September-4th October 1992 : 119-157, ed. R. Ciarla and F. Rispoli. Rome: Istituto Italiano per l'Africa e l'Oriente.

PRYCE, T. O.

2009 Copper Production and Technological Reproduction in the Khao Wong Prachan Valley of Central Thailand. Unpublished doctoral thesis. Institute of Archaeology, University College London, U.K. Available at http://oxford.academia.edu/OliverPryce.

Pryce, T. O., and M. J. Abrams

2010 Direct detection of Southeast Asian smelting sites by ASTER remote sensing imagery: Technical issues and future perspectives. Journal of Archaeological Science 37:3091-3098.

Pryce, T. O., B. Bellina, and A. Bennett

2008 The development of metal technologies in the Upper Thai-Malay Peninsula: Initial interpretation of the archaeometallurgical evidence from Khao Sam Kaeo. Bulletin de l'Ecole Française d'Extrême-Orient $93: 295-316$.

Pryce, T. O., M. Martinón-Torres, V. C. Pigott, and T. Rehren

2010 Prehistoric copper production and technological reproduction in the Khao Wong Prachan Valley of Central Thailand. Archaeological and Anthropological Sciences 2:237-264.

Pryce, T. O., and S. Natapintu

2009 Smelting iron from laterite: Technical possibility or ethnographic aberration? Asian Perspectives $48: 249-264$.

RENFREW, C., AND M. WAGSTAFF, EDS.

1982 An Island Polity: The Archaeology of Exploitation in Melos. Cambridge: Cambridge University Press.

RisPoli, F.

1990 La Ceramica Di Non Pa Wai (Lopburi, Tailandia Centrale). Unpublished doctoral thesis. Dipartimento di Studi Orientali, Universita' La Sapienza Roma.

1992 Preliminary report on the pottery of Tha Khae, Lopburi, Central Thailand, in Southeast Asian Archaeology 1990:129-142, ed. I. C. Glover. Hull: Centre for Southeast Asian Studies.

1997 Late third/early second millennium BCE pottery traditions in Central Thailand: Some preliminary observations in a wider prospective, in South-East Asian Archaeology 1992. Proceedings of the Fourth International Conference of the European Association of South-East Asian Archaeologists. Rome, 28th September-4th October 1992:59-67, ed. R. Ciarla and F. Rispoli. Rome: Istituto Italiano per l'Africa e l'Oriente.

2007 The incised and impressed pottery style of Mainland Southeast Asia following the paths of Neolithization. East and West $57: 235-304$.

Rispoli, F., R. Ciarla, and V. C. Pigott

2009 Towards a working chronology for Central Thailand: Revising the sequence for the Khao Wong Prachan Valley and the Greater Lopburi Region. Paper presented at the Indo-Pacific Prehistory Association in Hanoi, 29 November-5 December 2009. 
SitThithaworn, E.

1990 Metallogenic map of Thailand. Bangkok: Department of Mineral Resources.

Smith, M. E., C. Heath-Smith, R. Kohler, J. Odess, S. Spanogle, and T. Sullivan

1994 The size of the Aztec city of Yautepec: Urban survey in Central Mexico. Ancient Mesoamerica $5: 1-11$.

Sullivan, A. P., P. B. Mink, And P. M. Uphus

2007 Archaeological survey design, units of observation, and the characterization of regional variability. American Antiquity $72: 322-333$.

White, J. C., and E. G. Hamilton

2009 The transmission of Early Bronze technology to Thailand: New perspectives. Journal of World Prehistory $22: 357-397$.

White, J. C., And V. C. Pigott

1996 From community craft to regional specialisation: Intensification of copper production in prestate Thailand, in Craft Specialization and Social Evolution: In Memory of V. Gordon Childe: 151175, ed. B. Wailes. Philadelphia: University Museum Publications.

WiLKINSON, T. J.

2000 Regional approaches to Mesopotamian archaeology: The contribution of archaeological surveys. Journal of Archaeological Research 8:219-267.

Wright, J. C., J. F. Cherry, and E. Mantzourani

1990 The Nemea Valley Archaeological Project: A Preliminary Report. Hesperia 59:579-659.

WyATT, D. K.

2003 Thailand — a Short History, 2nd ed. New Haven, CT: Yale University Press.

\section{ABSTRACT}

Intensive surface surveys are a well-established method in the landscape archaeology of many parts of the world, but have remained relatively rare in Southeast Asian research. This article summarizes the contribution of existing surveys in the latter region and offers results from a short but informative survey of a metal-producing landscape in central Thailand. We argue that there is much to be gained from a fuller integration of systematic landscape reconnaissance into wider Southeast Asian research agendas and consider some of the strengths and weaknesses of such an approach in this cultural and physical environment. KEYwords: settlement survey, landscape, archaeometallurgy, Metal Age, Thailand, geoarchaeology. 